\title{
PRELIMINARY CYCLOSTRATIGRAPHIC RESULTS ON PLANKTONIC FORAMINIFERA FROM IODP-HOLE U1406A
}

\author{
$\underline{\text { Alessio Fabbrini }}{ }^{1}$ (1D) , Luca Foresi ${ }^{2}$ (D),${\text { Fabrizio } \text { Lirer }^{3} \text { (1) \& Nicola Pelosi }}^{3}$ \\ ${ }^{1}$ Department of Earth Sciences, University College London, Gower Street, London WC1E 6BT, United Kingdom; \\ ${ }^{2}$ Department of Physical Sciences, Earth and Environment, Via Laterina 8, Siena (SI) 53100, Italy; luca.foresi@unisi.it \\ ${ }^{3}$ Marine Science Institute (ISMAR) -CNR, Calata Porta di Massa, Napoli, 80133, Italy. fabrizio.lirer@iamc.cnr.it
}

\author{
KeYwORDS: \\ planktonic foraminifera; \\ cyclostratigraphy; early \\ Miocene; \\ North Atlantic.
}

\section{Bullet-Points Abstract}

- Cyclostratigraphic study conducted on early Miocene planktonic foraminifera quantitative data.

- Preliminary age model based on Paragloborotalia siakensis tied to Earth eccentricity cycles.

- Trilobatus and Paragloborotalia siakensis antiphasic relationship due to different paleocological affinities?

\section{INTRODUCTION}

Cyclostratigraphy is based on the recognition of astronomical-periodic signals in quantitative data from climate-sensitive proxies. Microfossils abundance, carbonate content, isotopic data, elemental ratios or any physical properties measurable at sufficient resolution are generally used. The climate changes are influenced by many factors at long time scale and the astronomical cycles (obliquity, eccentricity and precession, better known as the Milankovitch cycles) are among the most influent agents. In fact, a deep link exists between climate, sedimentation and orbitally forced insolation. The astronomical cycles influence the total amount and global distribution of solar energy reaching the Earth surface, producing cyclic lithologic variations and influencing organisms distribution in the oceans (Hinnov et al., 2007; 2012 and references therein). These variations can be detected at a smaller scale and high sampling resolution allows the tuning of sedimentary sequences and the bioevents documented within (Laskar et al., 2004; 2010).

The Astronomical Time Scale (ATS) was created using the astronomical tuning for the Neogene, Paleogene and parts of the Mesozoic (Hilgen et al., 2000; Lourens et al., 1996; Shackleton et al., 1995; Shackleton et al., 2000; Westerhold et al., 2014; Beddow et al., 2018). In 2006, a new astronomical model for the last $250 \mathrm{Ma}$ was proposed, combining the astronomical calibration of Laskar et al. (2004) and Laskar \& Boué (2010). The IODP Leg 154 at Ceara Rise provided the age calibration used for the oceanic biozonal scheme of Wade et al. (2011). Since Ceara Rise Leg had not reliable magnetostratigraphic data, astrochronology was the only tool to date that sequence. A great potential of IODP Site U1406 for astronomical tuning of the Oligocene/early Miocene supported by high resolution paleomagnetism emerged in Fabbrini et al. (2019).

\section{Materials ANd Methods}

This study investigated the interval 98.29-39.75 m with an average spacing between samples of 0.40 $\mathrm{m}$, covering the time interval 23.40-21.17 Ma. The temporal resolution obtained $(15 \mathrm{Ky})$ still allowed us to detect periodicities longer than $40 \mathrm{Ky}$, such as the $110 \mathrm{Ky}$ and $400 \mathrm{Ky}$ eccentricity cycles. The spectral analysis is based on the principle of decomposition of the signals in different components, assuming that any signal can be decomposed into a finite number of components (Huang et al., 2008). Each of them represents an embedded characteristic simple oscillation on a separated time-scale. Finally, the filtered signals can be correlated to astronomical cycles, such as orbital eccentricity (Laskar et al., 2004).

\section{Discussion AND Conclusion}

Paragloborotalia siakensis, Globigerina bulloides, Globoturborotalita occlusa and Catapsydrax group provided the most reliable results. All signals resulted stronger in the upper portion of the succession and weaker in the lower one, highlighting problems on the first age model adopted. That was based on paleomagnetic tie-points from van Peer et al. (2017) as discussed in Fabbrini et al. (2019). The uppermost interval of the succession $(47-39 \mathrm{~m})$ is not directly 


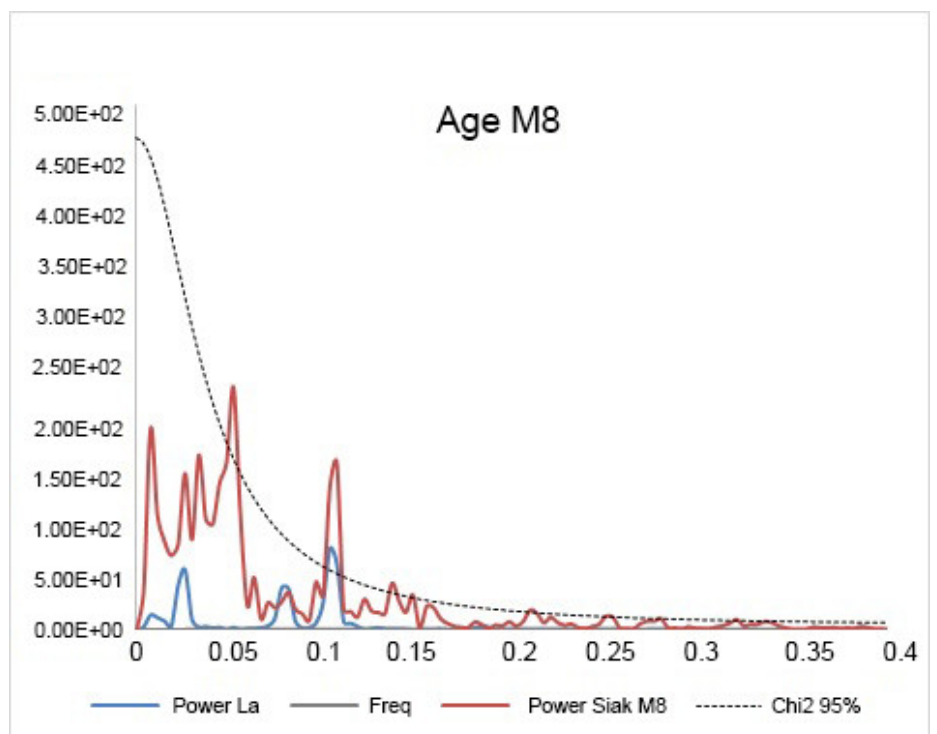

Fig. 1. Power spectrum of the Paragloborotalia siakensis curve (red) compared with Laskar 2004 eccentricity (blue) using the final age model (Age M8). Around frequency 0.1 (corresponding to $110 \mathrm{Ky}$ eccentricity cycle), a reliable match with the 2 components of the eccentricity signal $(\mathrm{F}=0.08$ and $\mathrm{F}=0.104)$ is evident in $P$. siakensis distribution data.

linked to the paleomagnetism and its age was inferred using the sedimentation rate calculated below (Fabbrini et al., 2019). The distortion in the signals from the spectral analysis suggests that the age model employed required corrections. Paragloborotalia siakensis and secondly G. bulloides resulted the most sensitive species to eccentricity cycles. Instead, the well-known relation Globigerinoides maxima/eccentricity minima (Lirer et al., 2002 and reference therein) is not applicable here, since Globigerinoides and Trilobatus are rare along the interval. The abundance of $G$. bulloides seems paced by $110 \mathrm{Ky}, 400 \mathrm{Ky}$ and $1.2 \mathrm{Ma}$ eccentricity cycles. Catapsydrax gr. shows less reliable signals, but the $110 \mathrm{Ky}$ and $400 \mathrm{Ky}$ cycles could still be pointed out. Paragloborotalia siakensis shows the strongest correspondence with the $110 \mathrm{Ky}, 400 \mathrm{Ky}$ and $1.2 \mathrm{Ma}$ eccentricity cycles. Thus, $P$. siakensis was selected to create a second age model. The power spectrum of $P$. siakensis matches with the power spectrum of the orbital eccentricity (Laskar et al., 2004) especially at $\mathrm{F}=0.1$ (110 Ky eccentricity cycle). A weaker correspondence can be seen with $400 \mathrm{Ky}$ periodicity $(\mathrm{F}=0.025)$. The cross-correlation test between $P$. siakensis and the filtered curve from Laskar et al. (2004) confirmed higher reliability in the upper part of the section requiring a third age model. Each peak of the P. siakensis distribution was correlated to each peak of the eccentricity curve from Laskar et al. (2004). The power spectra of $P$. siakensis and Laskar et al. (2004) match especially around $\mathrm{F}=0.08$ and $\mathrm{F}=0.104$ (Fig. 1). Thus, iteratively and using the $400 \mathrm{Ky}$ periodicity as an additional checking tool, the P. siakensis filtered curve has been adjusted to achieve the final age model. This model was based on $P$. siakensis filtered at $\mathrm{F}=0.1$ -



Fig. 2. 400 Ky cycle comparison between P. siakensis, G. bulloides and eccentricity curve (Laskar at al., 2004). Time is represented on the $\mathrm{x}$ axis. The figure shows in pale blue the eccentricity curve not filtered and a filtered version dashed pale blue line for direct comparison with the filtered curve of G. bulloides (brown) and P. siakensis (blue line). The antiphasic relationship between $G$. bulloides and P. siakensis emerges clearly. The narrow pass-band filter was applied at $\mathrm{F}=0.024-0.026$. 
0.104 offering the highest correspondence with the eccentricity curve, maintaining optimum results also whether filtered at $\mathrm{F}=0.025$ ( $400 \mathrm{Ky}$ eccentricity cycle). Paragloborotalia siakensis and $G$. bulloides filtered at the same frequency $(\mathrm{F}=0.025)$, clearly show opposite and antiphasic behaviour (Fig. 2).

Another comparison was made between P. siakensis, G. bulloides and Trilobatus group, where Trilobatus group and Globigerina bulloides show a similar sensitivity to astronomical cycles. Both these taxa are antiphasic with $P$. siakensis in contrast with previous literature (Lirer et al., 2002 and reference therein). Trilobatus group and $G$. bulloides are both open ocean mixed layer taxa, but with different trophic and climatic affinity and preference. In fact, Trilobatus and Globigerinoides are typical of oligotrophic conditions and warm/ warm-temperate stratified waters, while $G$. bulloides lives in eutrophic conditions in temperate and nutrient rich - well mixed waters. A possible explanation could be a different behaviour and climatic affinity of $T$. primordius in respect with the other taxa of the Globigerinoides plexus. These preliminary data will lead to further investigations on carbonate content and magnetic susceptibility to answer these questions.

\section{REFERENCES}

Beddow H.M., Liebrand D., Wilson D.S., Hilgen F.J., Sluijs A., Wade B.S. \& Lourens L.J. (2018). Astronomical tunings of the Oligocene-Miocene transition from Pacific Ocean Site U1334 and implications for the carbon cycle. Climate of the Past, 14 (3): 255-270.

Fabbrini A., Baldassini N., Caricchi C., Di Stefano A., Dinarès Turell J., Foresi L., Lirer F., Patricolo S., Sagnotti L. \& Winkler A. (2019). Integrated quantitative calcareous plankton bio-magnetostratigraphy of the Early Miocene from IODP Leg 342, Hole U1406A (Newfoundland Ridge, NW Atlantic Ocean). Stratigraphy and Geological Correlation, 27 (2): 259-276. doi. 10.1134/S0869593819020023.

Hilgen F.J., Iaccarino S., Krijgsman W., Villa G., Langereis C.G. \& Zachariasse W.J. (2005). The global boundary stratotype section and point (GSSP) of the Messinian Stage (uppermost Miocene). Episodes, 23 (3): 172-8.

Hinnov L.A. \& Ogg J.G. (2007). Cyclostratigraphy and the astronomical time scale. Stratigraphy, 4 (2-3), 239-251.
Hinnov L.A. \& Hilgen F.J. (2012). Cyclostratigraphy and astrochronology. In: The geologic time scale 2012 (pp. 63-83).

Huang N. E., \& Wu Z. (2008). A review on Hilbert-Huang transform: Method and its applications to geophysical studies. Reviews of geophysics, 46 (2).

Laskar J., Robutel P., Joutel F., Gastineau M., Correia A. C. M. \& Levrard B. (2004). A long-term numerical solution for the insolation quantities of the Earth. Astronomy \& Astrophysics, 428 (1): 261-285.

Laskar J. \& Boué G. (2010), Explicit expansion of the threebody disturbing function for arbitrary eccentricities and inclinations. Astronomy \& Astrophysics. Nov, 522: A60.

Lirer F., Caruso A., Foresi L.M., Sprovieri M., Bonomo S., Di Stefano A., Di Stefano E., Iaccarino S.M., Salvatorini G., Sprovieri R. \& Mazzola S. (2002). Astrochronological calibration of the upper Serravallian/lower Tortonian sedimentary sequence at Tremiti Islands (Adriatic Sea, southern Italy). Rivista Italiana di Paleontologia e Stratigrafia 108 (2): 241-256.

Lourens L.J., Antonarakou A., Hilgen F.J., Van Hoof A.A., Vergnaud-Grazzini C. \& Zachariasse W.J. (1996). Evaluation of the Plio-Pleistocene astronomical timescale. Paleoceanography and Paleoclimatology, 11 (4): 391-413.

Shackleton N.J., Crowhurst S., Hagelberg T., Pisias N.G. \& Schneider D.A. (1995). A new late Neogene time scale: application to Leg 138 sites. In Proc. ODP, Sci. Results 1995, Vol. 138: 73-101.

Shackleton N.J., Hall M.A., Raffi I., Tauxe L. \& Zachos J. (2000). Astronomical calibration age for the OligoceneMiocene boundary. Geology 28 (5): 447-50.

van Peer T.E., Xuan C., Lippert P.C., Liebrand D., Agnini C. \& Wilson P.A. (2017). Extracting a detailed magnetostratigraphy from weakly magnetized, Oligocene to early Miocene sediment drifts recovered at IODP Site U1406 (Newfoundland Margin, Northwest Atlantic Ocean). Geochemistry, Geophysics, Geosystems 18 (11): 3910-3928.

Wade B.S., Pearson P.N., Berggren W.A. \& Pälike H. (2011). Review and revision of Cenozoic tropical planktonic foraminiferal biostratigraphy and calibration to the geomagnetic polarity and astronomical time scale. Earth-Science Reviews, 104 (1-3): 111-142.

Westerhold T., Röhl U., Pälike H., Wilkens R., Wilson P. A. \& Acton G.D. (2014). Orbitally tuned time scale and astronomical forcing in the middle Eocene to early Oligocene. Climate of the Past, 10 (3): 955-973. doi:10.5194/cp-10-955-2014. 